\title{
KADAR KASIUM SERUM PADA PASIEN DIABETES MELLITUS TIPE 2 DI RSUD DR. DORIS SYLVANUS PALANGKARAYA
}

\author{
Serum Calcium Level in Patient with Type 2 Diabetes Mellitus \\ in Doris Sylvanus Hospiltal of Palangkaraya \\ ${ }^{1 * D w i}$ Purbayanti, ${ }^{2}$ Nirma Jayanti, ${ }^{3}$ Noor Fadillah \\ 1,2,3Program Studi Analis Kesehatan, Universitas Muhammadiyah Palangkaraya, Palangka Raya, Indonesia \\ *e-mail : dwipurbayanti@gmail.com
}

\begin{abstract}
ABSTRAK
Sekresi insulin dan glukogon serta resistensi insulin merupakan proses yang bergantung pada homeostasis kalsium. Penelitian ini bertujuan untuk mengetahui apakah pada pasien diabetes mellitus tipe 2 terjadi peningkatan kadar kalsium serum.. Subjek sebanyak 34 pasien DM tipe-2 berjenis kelamin perempuan yang berusia $\geq 40$ tahun dipilih melalui teknik purposive sampling. Penelitian telah dilakukan pada bulan Juni 2018. Pengukuran kadar kalsium serum dilakukan di Universitas Muhammadiayah Palangkaraya menggunakan metode Arsenazo dengan instrumen BTS 350. Hasil penelitian menunjukkan sebanyak 79\% pasien DM tipe-2 yang memiliki kadar kalsium serum >normal $(>10 \mathrm{mg} / \mathrm{dL})$ dan $21 \%$ kadar kalsium normal. Terdapat hubungan yang sangat lemah antara kadar kalsium serum terhadap usia, lama menderita dan GDP. Kadar kalsium serum terlihat meningkat pada pasien DM tipe-2 dengan komplikasi penyakit jantung. Dalam penelitian ini kami menemukan adanya peningkatan kadar kalsium serum pada pasien DM tipe-2 dan bisa digunakan dalam perawatan pada pasien diabetes.
\end{abstract}

Kata kunci : kalsium serum, DM tipe-2, hiperkalsemia

\section{ABSTRACT}

Insulin and glucogone secretion, and insulin resistance are processes that depend on calcium homeostasis. This study aims to determine patients with type 2 diabetes mellitus has been increase in serum calcium levels. The subjects of this study are 34 famale patients aged $\geq 40$ years old with type- 2 diabetes mellitus were selected by purposive sampling technique. This study was conducted in June 2018. Measurement of serum calcium levels was at the University Muhammadiayah Palangkaraya using Arsenazo method with BTS 350 instruments. The results showed $79 \%$ of type-2 diabetes mellitus patients had serum calcium levels >normal (>10 $\mathrm{mg} / \mathrm{dL}$ ) and $21 \%$ normal calcium levels. The correlation is very weak between serum calcium levels on age, duration and GDP. Serum calcium levels are seen to increase in patients with type-2 diabetes mellitus with complications of heart disease. In this study we found the increasing serum calcium levels in type-2 diabetes mellitus patients and could be used in the treatment of diabetic patients.

Keyword : serum calcium, type-2 diabetes mellitus, hypercalcemia

\section{PENDAHULUAN}

Diabetes mellitus (DM) adalah kondisi serius jangka panjang dengan dampak besar pada kehidupan dan kesejahteraan individu, keluarga, dan masyarakat di seluruh dunia. Ini adalah salah satu dari 10 penyebab utama kematian pada orang dewasa, dan diperkirakan telah menyebabkan empat juta kematian secara global pada tahun 2017 (IDF, 2017).

Tiga jenis diabetes yang utama adalah diabetes tipe 1 (DM tipe-1), diabetes tipe 2 (DM Tipe-2), dan diabetes gestational. Sejak tahun 2000, International Diabetes Federation (IDF) telah melaporkan kejadian diabetes nasional, regional dan global. Pada tahun 2009 diperkirakan 285 juta orang menderita diabetes (gabungan DM Tipe-1 dan DM Tipe-2), meningkat menjadi 366 juta pada 2011, 382 juta pada 2013, 415 juta pada 2015, 425 juta pada 2017 dan 463 juta pada 2019. Serta diperkirakan sekitar 578 juta orang menderita diabetes pada tahun 2030 dan meningkat $51 \%$ (700 juta) pada tahun 2045. Sedangkan Indonesia, menempati urutan ke-7 penderita diabetes di seluruh dunia dengan angka sekitar 10,7 juta pada 
tahun 2019 dan 13,7 juta di tahun 2030 (Saeedi et al., 2019).

DM tipe-2 merupakan tipe diabetes yang paling banyak dengan angka sekitar 90\% dari total kasus diabetes yang menyebabkan komplikasi mikrovaskular dan makrovaskuler (Chatterjee et al., 2017). Pada pasien DM tipe-2, hiperglikemia disebabkan oleh produksi insulin yang tidak memadai akibat disfungsi sel sel $\beta$ pankreas dan atau resistensi insulin akibat ketidakmampuan tubuh untuk merespons sepenuhnya terhadap insulin (IDF, 2017). Efek dari hiperglikemia jangka panjang dari diabetes mellitus diantaranya adalah memiliki risiko tinggi terhadap komplikasi mikrovaskuler yakni retinopati, nefropati, dan neuropati. Penyempitan arteri menyebabkan penurunan aliran darah ke jantung, atau ke otak, atau anggota tubuh yang menyebabkan beberapa komplikasi makrovaskular seperti penyakit kardiovaskuler dan stroke (Chatterjee et al., 2017).

Kalsium adalah elemen yang memainkan peran penting tidak hanya dalam mineralisasi tulang tetapi juga dalam berbagai fungsi biologis seperti optimalisasi transmisi impuls saraf, kontraksi otot, pembekuan darah, sekresi hormon, dan adhesi antar sel. Di dalam plasma darah, kalsium memiliki tiga jenis yakni sekitar $50 \%$ bebas, $40 \%$ terikat dengan protein plasma terutama albumin dan $10 \%$ kompleks dengan anion kecil. Fraksi kalsium bebas adalah bentuk yang aktif secara biologis, konsentrasinya dalam plasma diatur dengan ketat oleh hormon pengatur kalsium paratiroid hormone (PTH) dan vitamin D (Bishop et al., 2017).

Menurut Hus et al. (2019) penyebab hipokalsemia adalah hipoparatiroidisme, hipomagnesemia, defisiensi vitamin D akibat malnutrisi, penyakit hati kronis, sindrom nefrotik, pankreatitis akut, penyakit ginjal. Serta hipoalbuminemia (namun hanya kalsium total yang terpengaruh, sedangkan kalsium ion tidak terpengaruh). Penyebab hiperkalsemia adalah hiperparatiroidisme, hipertiroidisme, hipokalsiuria, multiple mieloma, kelebihan vitamin $\mathrm{D}$, diuretik Thiazide, imobilisasi berkepanjangan.

Sekresi insulin dan glukogon serta resistensi insulin merupakan proses yang bergantung pada homeostasis kalsium (Rorsman et al., 2012). Ketika kadar glukosa darah meningkat, glukosa diangkut ke dalam sel dengan bantuan transporter GLUT-4. Kemudian glukosa dikonversi menjadi glukosa-6- fosfat dengan bantuan glucokinase, selanjutnya dioksidasi untuk menghasilkan ATP yang menyebabkan depolarisasi membrane sel akibat penutupan saluran kalium. Depolarisasi ini menyebabkan peningkatan fluks kalsium melalui saluran kalsium yang menyebabkan docking, vesikel yang mengandung insulin menyatu dengan membran sel. Insulin tersebut kemudian disekresikan oleh eksositosis (Kanchana et al., 2014). Peningkatan kadar kalsium intraseluler telah terbukti mengurangi efek insulin dalam adiposit karena berkurangnya jumlah transporter glukosa (GLUT-4) dan penurunan aktivitas reseptor insulin. Akibatnya, peningkatan kadar kalsium dapat menurunkan ekspresi transporter GLUT-4 yang berakibat pada berkurangnya penyerapan glukosa sehingga mengakibatkan peningkatan konsentrasi glukosa dalam plasma (Becerra-Tomás et al., 2014).

Kelainan homeostasis kalsium sering terjadi pada pasien diabetes dan dikaitkan dengan gangguan ginjal atau hipo atau hiperparatiroidisme, yang dapat mengakibatkan gangguan homeostasis kalsium (Ahn et al., 2017). Penelitian sebelumnya melaporkan bahwa kadar kalsium total serum lebih tinggi pada individu dengan diabetes dibandingkan dengan yang tidak diabetes (Becerra-Tomás al et., 2014). Selain itu, peningkatan risiko diabetes juga diamati pada orang Korea usia pralansia dan lansia dengan peningkatan konsentrasi kalsium serum (Kim et al., 2010). Namun penelitian Hus et al. (2019) melaporkan kalsium serum yang lebih rendah pada pasien diabetes dibandingkan dengan tidak diabetes. Sehingga kami juga bermaksud untuk mengetahui kadar kalsium serum pada pasien Diabetes Melitus Tipe-2 di RSUD Dr. Doris Sylvanus Palangka Raya.

\section{METODE PENELITIAN}

Penelitian ini merupakan penelitian deskriptif dengan jenis Cross Sectional Study. Diperoleh sebanyak 34 orang pasien DM Tipe-2 berjenis kelamin perempuan dengan usia $\geq 40$ tahun. Pengambilan sampel dilakukan pada bulan Juni 2018 di RSUD Dr. Doris Sylvnus Palangka Raya. Pemilihan sampel berdasarkan teknik purposive sampling, dengan krteria inklusi menderita diabetes lebih dari atau sama dengan 1 tahun, tidak 
mengkonsumsi alkohol, pasien rawat jalan yang rutin dalam pengontrolan kadar glukosa darahnya, dan kami mengeksklusi jika pasien mengkonsumsi suplemen vitamin D atau kalsium.

Sebelumnya pasien diminta untuk mengisi lembar informed consent sebagai pernyataan kesediaan sebagai responden dalam penelitian ini. Kemudian pengambilan sampel darah dilakukan pada kondisi aseptik dari fossa cubiti (vena) sebanyak 3 $\mathrm{mL}$. Selanjutnya darah dimasukkan ke dalam tabung vakum tutup kuning dan dibiarkan sekitar 15 menit agar proses pembekuan maksimal. Serum diperoleh setelah dilakukan pemisahan menggunakan sentrifuse pada kecepatan 3000-4000 rpm. Serum yang diperoleh kemudian dilakukan pemeriksaan glukosa darah di bagian laboratorium klinik RSUD Dr. Doris Sylvanus menggunakan metode GOD-PAP. Sisa serum kemudian di simpan dalam tabung mikro dan di bawa ke Universitas Muhammadiyah Palangkaraya untuk diperiksa kadar kalsium totalnya menggunakan metode Arsenazo. Arsenazo III secara kimia stabil dan memiliki afinitas yang sangat tinggi untuk kalsium dalam kisaran $\mathrm{pH}$ netral. Arsenazo III akan membentuk kompleks Arsenazo III - Kalsium yang berwarna biru dengan absorbansi maksimum pada $650 \mathrm{~nm}$. Konsentrasi kalsium sebanding dengan absorbansi dari kompleks Arsenazo III - kalsium yang berwarna biru. Instrumen yang digunakan adalah BTS-350 dan kontrol serum level 1 dan 2 dari biosystem. Analisis korelasi digunakan untuk mencari hubungan antara variable usia, lama menderita dan kadar glukosa darah puasa (GDP) terhadap kadar kalsium.

\section{HASIL DAN PEMBAHASAN}

Sebanyak 34 pasien Diabetes Mellitus Tipe-2 berjenis kelamin perempuan dengan rentang usia 4065 tahun bersedia untuk menjadi subjek dalam penelitian ini. Seluruh subjek adalah pasien rawat jalan pada bulan Juni 2018 yang rutin berobat dan memantau kadar glukosa darahnya ke RSUD Dr. Doris Sylvanus Palangka Raya. Karakteristik pasien secara rinci terlihat pada TABEL 1.

TABEL 1. Karakteristik Pasien DM Tipe-2

\begin{tabular}{lcc} 
KARAKTERISTIK & $\begin{array}{c}\text { Frekuensi } \\
\mathbf{N}=\mathbf{3 4}\end{array}$ & $\begin{array}{c}\text { Persentase } \\
(\%)\end{array}$ \\
\hline USIA & &
\end{tabular}

\begin{tabular}{lcc}
$40-59$ & 22 & 64,7 \\
$>60$ & 12 & 35,3 \\
\hline KOMPLIKASI & & \\
Hipertensi & 4 & 11,8 \\
Jantung & 7 & 20,6 \\
$\quad$ Tidak Ada & 23 & 67,6 \\
\hline LAMA MENDERITA & & \\
$\quad \leq 5$ tahun & 22 & 64,7 \\
$\quad$ 5 tahun & 12 & 35,3 \\
\hline KADAR GDP & & \\
$\leq 130 \mathrm{mg} / \mathrm{dL}$ & 5 & 14,7 \\
$>130 \mathrm{mg} / \mathrm{dL}$ & 29 & 85,3 \\
\hline
\end{tabular}

Hasil penelitian terhadap 34 sampel pasien DM tipe-2 diperoleh data sebanyak 7 sampel (21\%) memiliki kadar kalsium normal dan sebanyak 27 sampel (79\%) memiliki kadar kalsium diatas normal.

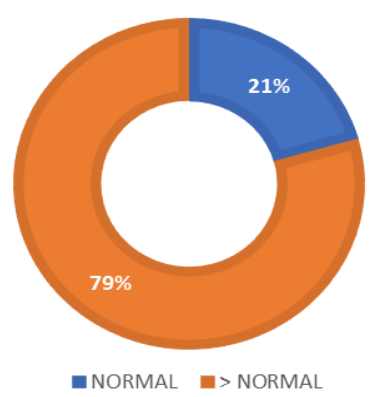

GAMBAR 1. Hasil Pemeriksaan Kalsium pada Pasien DM Tipe-2

Pada gambar 1, terlihat sebagian besar pasien memiliki kadar kalsium > normal (> 10,0 mg/dL). Hasil ini sesuai dengan penelitian Becerra-Tomás et al. (2014) dan Suh et al. (2017). DM Tipe-2 ditandai dengan resistensi insulin dan gangguan sekresi insulin. Sekresi insulin adalah proses yang tergantung kalsium, sehingga perubahan fluks kalsium pada sel$\beta$ pankreas dapat mempengaruhi fungsi sekresi insulin oleh sel- $\beta$ pankreas (Suh et al., 2017). Menurut Kim et al. (2010), bahwa fungsi sel- $\beta$ pankreas berhubungan negatif dengan kadar kalsium serum total. Konsentrasi kalsium yang tinggi dapat menyebabkan penurunan sekresi insulin dari sel-sel $\beta$ pankreas dan meningkatkan risiko perkembangan diabetes (Becerra-Tomás et al., 2014).

TABEL 2. Hasil Pemeriksaan Kadar Kalsium pada Pasien DM Tipe-2 Berdasarkan Usia

\begin{tabular}{cccc}
\hline Usia & $\begin{array}{c}\text { Normal } \\
\mathbf{N = 7}\end{array}$ & $\begin{array}{c}>\text { Normal } \\
\mathbf{N = 2 7}\end{array}$ & $\begin{array}{c}\text { Rerata } \\
(\mathbf{m g} / \mathbf{d L})\end{array}$ \\
\hline $40-59$ & 5 & 17 & 10,87 \\
\hline$>60$ & 2 & 10 & 11,23 \\
\hline
\end{tabular}




\section{BJMLT}

TABEL 3. Hasil Analisis Korelasi Antara Usia dan Kadar Kalsium Serum pada Pasien DM Tipe-2

\begin{tabular}{l|r|r}
\hline & Usia (tahun) & $\begin{array}{c}\text { Kalsium Serum } \\
(\mathrm{mg} / \mathrm{dL})\end{array}$ \\
\hline Usia (tahun) & 1 & \\
\hline Kalsium Serum (mg/dL) & 0,039881833 & 1 \\
\hline
\end{tabular}

Tabel 2 menampilkan profil kadar kalsium pada pasien DM tipe-2 berdasarkan usia, terlihat rerata kadar kalisum lebih tinggi pada usia >60 tahun lansia. Kim et al. (2010) melaporkan penelitiannya pada orang korea dengan diabetes usia $\geq 40$ tahun, menemukan adanya hubungan antara kadar kalsium serum perempuan yang telah menopouse dengan nilai yang lebih tinggi dibandingkan yang belum menopouse, yang berkaitan dengan hormon seks pada perempuan. Namun dalam penelitian ini kami menemukan hubungan yang positif sangat lemah yakni 0,04 antara usia dengan kadar kalsium serum, sebagaimana hasil analisis korelasi pada tabel 3.

TABEL 4. Hasil Pemeriksaan Kadar Kalsium pada Pasien DM Tipe-2 Berdasarkan Lama Menderita

\begin{tabular}{cccc}
$\begin{array}{c}\text { Lama } \\
\text { Menderita }\end{array}$ & $\begin{array}{c}\text { Normal } \\
\mathbf{N = 7}\end{array}$ & $\begin{array}{c}>\text { Normal } \\
\mathbf{N = 2 7}\end{array}$ & $\begin{array}{c}\text { Rerata } \\
(\mathbf{m g} / \mathbf{d L})\end{array}$ \\
\hline$\leq 5$ tahun & 5 & 17 & 11,21 \\
\hline$>5$ tahun & 2 & 10 & 10,61 \\
\hline
\end{tabular}

TABEL 5. Hasil Analisis Korelasi Antara Lama Menderita dengan Kadar Kalsium Serum pada Pasien DM Tipe-2

\begin{tabular}{lrrr}
\hline & $\begin{array}{c}\text { Lama Menderita } \\
\text { (tahun) }\end{array}$ & $\begin{array}{c}\text { Kalsium Serum } \\
(\mathrm{mg} / \mathrm{dL})\end{array}$ \\
\hline Lama Menderita (tahun) & 1 & \\
\hline Kalsium Serum (mg/dL) & $-0,069252718$ & 1 \\
\hline
\end{tabular}

Berdasarkan lama menderita terlihat rerata kadar kalsium lebih tinggi pada pasien DM tipe-2 yang menderita $<5$ tahun. Hal ini sejalan dengan penelitian Hus et al. (2019) yang menatakan adanya hhubungan terbalik antara kadar kalsium serum dengan lama menderita diabetes. Dari hasil uji korelasi, diperoleh hubungan yang negatif sangat lemah yakni $-0,07$.

TABEL 6. Hasil Pemeriksaan Kadar Kalsium pada Pasien DM Tipe-2 Berdasarkan Kadar Glukosa Darah Puasa (GDP)

\begin{tabular}{cccc}
\hline Kadar GDP & $\begin{array}{c}\text { Normal } \\
\mathbf{N = 7}\end{array}$ & $\begin{array}{c}>\text { Normal } \\
\mathbf{N = 2 7}\end{array}$ & $\begin{array}{c}\text { Rerata } \\
(\mathbf{m g} / \mathbf{d L})\end{array}$ \\
\hline$\leq 130 \mathrm{mg} / \mathrm{dL}$ & 1 & 4 & 11,89 \\
\hline$>130 \mathrm{mg} / \mathrm{dL}$ & 6 & 23 & 10,84 \\
\hline
\end{tabular}

TABEL 7. Hasil Analisis Korelasi Antara Kadar Glukosa Darah Puasa (GDP) dengan Kadar Kalsium Serum pada Pasien DM Tipe-2

\begin{tabular}{|lrrr}
\hline & $G D P(m g / d L)$ & $\begin{array}{c}\text { Kalsium Serum } \\
(m g / d L)\end{array}$ \\
\hline GDP $(\mathrm{mg} / \mathrm{dL})$ & 1 & \\
\hline Kalsium Serum $(\mathrm{mg} / \mathrm{dL})$ & $-0,113766443$ & \\
\hline
\end{tabular}

Pasien diabetes harus selalu melakukan kontrol kadar glukosa darah untuk mengurangi risiko komplikasi. Menurut Perkeni (2015) ada beberapa kriteria pengendalian diabetes diantaranya adalah memiliki kadar glukosa darah puasa (GDP) 80-130 $\mathrm{mg} / \mathrm{dL}$. Dari 34 pasien DM tipe-2 yang menjadi subjek penelitian, hanya 5 orang dengan pengendalian yang baik dan sebagian besar pengendaliannya tidak baik.

Hasil pemeriksaan kadar kalsium serum diperoleh rerata lebih tinggi pada pasien dengan kadar GDP $\leq 130 \mathrm{mg} / \mathrm{dL}$. Hasil analisis korelasi diperoleh hubungan yang negatif yakni $-0,11$ yang berarti hubungan yang lemah antara kadar GDP dengan kadar kalsium serum. Hasil yang sama juga dilaporkan (Kanchana et al., 2014).

TABEL 8. Hasil Pemeriksaan Kadar Kalsium pada Pasien DM Tipe-2 Berdasarkan Komplikasi yang Dimiliki

\begin{tabular}{cccc} 
Komplikasi & $\begin{array}{c}\text { Normal } \\
\mathbf{N = 7}\end{array}$ & $\begin{array}{c}>\text { Normal } \\
\mathbf{N = 2 7}\end{array}$ & $\begin{array}{c}\text { Rerata } \\
(\mathbf{m g} / \mathbf{d L})\end{array}$ \\
\hline Hipertensi & 1 & 3 & 10,58 \\
\hline Jantung & 0 & 7 & 11,63 \\
\hline Tidak Ada & 6 & 17 & 10,62 \\
\hline
\end{tabular}

Berdasarkan jenis komplikasi yang diderita oleh pasien DM Tipe-2, terlihat pada tabel 4 bahwa pasien dengan komplikasi penyakit jantung memiliki rerata kadar kalsium serum yang lebih tinggi. Hal ini sejalan Becerra-Tomás et al. (2014) bahwa terjadi peningkatan kadar kalsium serum pada pasien diabetes yang memiliki risiko tinggi penyakit kardiovaskuler. Serta sejalan dengan hasil penelitian Jorde et al. (1999) bahwa individu dengan riwayat infark miokard memiliki kadar kalsium serum yang lebih tinggi dibandingkan dengan yang tanpa infrak miokard.

Hipertensi merupakan salah satu faktor risiko penyakit kardiovaskuler dan penurunan fungsi ginjal. Hipertensi pada diabetes dapat mempercepat perkembangan nefrophati diabetik (Arauz-Pacheco et 
al., 2002). Beberapa penelitian melaporkan bahwa terjadi peningkatan kadar kalsium serum pada individu dengan hipertensi (Jorde et al., 1999; Sabanayagam and Shankar, 2011; Behradmanesh and Nasri, 2013). Namun dalam penelitian kami memiliki rerata kadar kalsium serum yang lebih rendah dibandingkan yang tidak memiliki komplikasi. Sejalan dengan penelitian kami, dilaporkan oleh Hazari et al. (2012) bahwa terjadi penurunan yang signifikan kadar kalsium serum pada pasien hipertesi dibandingkan yang normotensi.

\section{KESIMPULAN}

Hasil penelitian ini mendukung pendapat bahwa pada pasien diabetes mellitus tipe-2 terjadi peningkatan kalsium serum dan peningkatan yang lebih tinggi terjadi pada pasien DM tipe-2 dengan komplikasi penyakit jantung.

\section{DAFTAR PUSTAKA}

Ahn, C., Kang, J.H., Jeung, E.B., 2017. Calcium homeostasis in diabetes mellitus. J. Vet. Sci. 18, 261-266.

Arauz-Pacheco, C., Parrott, M.A., Raskin, P., 2002. The Treatment of Hypertension in Adult Patients With Diabetes. Diabetes Care 25, 134147.

Becerra-Tomás, N., Estruch, R., Bulló, M., Casas, R., Díaz-López, A., Basora, J., Fitó, M., SerraMajem, L., Salas-Salvadó, J., 2014. Increased serum calcium levels and risk of type 2 diabetes in individuals at high cardiovascular risk. Diabetes Care 37, 3084-3091.

Behradmanesh, S., Nasri, H., 2013. Association of serum calcium with level of blood pressure in type 2 diabetic patients. J. Nephropathol. 2, 254-257.

Chatterjee, S., Khunti, K., Davies, M.J., 2017. Type 2 diabetes. Lancet 389, 2239-2251.

Hazari, M.A.H., Arifuddin, M.S., Muzzakar, S., Devender Reddy, V., 2012. Serum calcium level in hypertension. N. Am. J. Med. Sci. 4, 569-572.
Hus AI, Tahleel B, Hasan AEI, Albagir EH, Mohammad MA, Salah S, Elmahdi SA (2019) Serum Calcium Level in Type 2 Diabetes Mellitus in Khartoum State. Clin Microbiol 8: 332.

International Diabetes Federation. IDF Diabetes Atlas, 8th ed. Brussels, Belgium: International Diabetes Federation; 2017

Jorde, R., Sundsfjord, J., Fitzgerald, P., Bønaa, K.H., 1999. Serum calcium and cardiovascular risk factors and diseases: The Tromso Study. Hypertension 34, 484-490.

Kanchana, N., Nandhini, R., Saikumar, P., 2014. Serum calcium and vitamin D levels in type 2 diabetes mellitus. Res. J. Pharm. Biol. Chem. Sci. 5, 583-588.

Kim, M.K., Kim, G., Jang, E.H., Kwon, H.S., Baek, K.H., Oh, K.W., Lee, J.H., Yoon, K.H., Lee, W.C., Lee, K.W., Son, H.Y., Kang, M. Il, 2010. Altered calcium homeostasis is correlated with the presence of metabolic syndrome and diabetes in middle-aged and elderly Korean subjects: The Chungju Metabolic Disease Cohort study (CMC study). Atherosclerosis 212, 674-681.

PERKENI, 2015, Pengelolaan dan Pencegahan Diabetes Melitus Tipe 2 di Indonesia, PERKENI, Jakarta.

Rorsman, P., Braun, M., Zhang, Q., 2012. Regulation of calcium in pancreatic $\alpha$ - and $\beta$-cells in health and disease. Cell Calcium 51, 300-308.

Sabanayagam, C., Shankar, A., 2011. Serum calcium levels and hypertension among US adults. J. Clin. Hypertens. 13, 716-721.

Saeedi, P., Petersohn, I., Salpea, P., Malanda, B., Karuranga, S., Unwin, N., Colagiuri, S., Guariguata, L., Motala, A.A., Ogurtsova, K., Shaw, J.E., Bright, D., Williams, R., 2019. Global and regional diabetes prevalence estimates for 2019 and projections for 2030 and 2045: Results from the International Diabetes Federation Diabetes Atlas, 9th edition. Diabetes Res. Clin. Pract. 157.

Suh, S., Bae, J.C., Jin, S.M., Jee, J.H., Park, M.K., 
BJMLT

Kim, D.K., Kim, J.H., 2017. Serum calcium changes and risk of type 2 diabetes mellitus in Asian population. Diabetes Res. Clin. Pract. 133, 109-114. 